
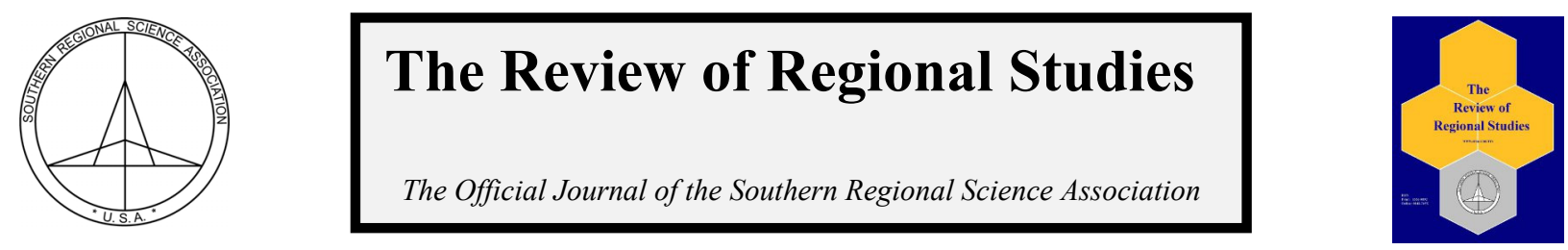

\title{
Peer Effects and Political Participation: What is the Role of Coursework Clusters?*
}

\author{
Olugbenga Ajilore ${ }^{\mathrm{a}}$, Gayle Alberda ${ }^{\mathrm{b}}$ \\ ${ }^{a}$ Department of Economics, University of Toledo,USA \\ ${ }^{b}$ Department of Politics, Fairfield University, USA
}

\begin{abstract}
This study addresses the role of peer civic engagement during adolescence on political participation in adulthood. We focus on novel specification based on an alternative peer group: the coursework cluster, which is constructed using an algorithm based on course taking habits. This paper explores how peers within course-taking clusters affect future political participation. The civic identities and politically oriented norms developed may be passed on through these classmates. Our results show that the influence of the peer group is from peers who perform better (have a higher grade point average) in social studies courses and from peers who participate in extracurricular activities.
\end{abstract}

Keywords: peer effects, civic engagement, coursework clusters, spatial Durbin error model, Add Health

JEL Codes: F43, R15, R12

\section{INTRODUCTION}

In 2008, voter turnout by individuals between the ages of 18 and 24 was 44.1 percent, which is higher than it has been since the voting age was lowered to 18 in 1972. Since 1972, the voting rates for individuals aged 18 to 24 have been consistently 20 to 30 percentage points lower than that for older individuals (File, 2014). Figure 1 shows the difference in turnout rates for individuals aged 18 to 24 compared to individuals aged 25 to 44 and 45 to 64 .

While the most recent numbers are promising in terms of higher youth voter turnout, these turnout rates still lag behind those of older cohorts. There are a variety of theories that attempt to explain low youth voter turnout, ${ }^{1}$ but only recently have these theories addressed the role of peers. ${ }^{2}$ The study of peer effects has brought a new understanding of adolescent behavior in terms of academic achievement, obesity-related behaviors, and delinquent behaviors. A focus

\footnotetext{
* Dr. Ajilore acknowledges financial support from the Spencer Foundation's New Civics Program (Grant \#201600096). This research uses data from Add Health, a program project directed by Kathleen Mullan Harris and designed by J. Richard Udry, Peter S. Bearman, and Kathleen Mullan Harris at the University of North Carolina at Chapel Hill, and funded by grant P01HD31921 from the Eunice Kennedy Shriver National Institute of Child Health and Human Development, with cooperative funding from 23 other federal agencies and foundations. Special acknowledgment is due Ronald R. Rindfuss and Barbara Entwisle for assistance in the original design. Information on how to obtain the Add Health data files is available on the Add Health website (http://www.cpc.unc.edu/addhealth). No direct support was received from grant P01-HD31921 for this analysis.

Olugbenga Ajilore is an Associate Professor of Economics at the University of Toledo and Gayle Alberda is an Assistant Professor of Politics at Fairfield University. Corresponding Author: O. Ajilore E-mail: gbenga.ajilore@utoledo.edu

${ }^{1}$ Highton and Wolfinger (2001) test the theory that transitions to adulthood affect turnout, but do not find any support for the traditional theories.

${ }^{2}$ A special issue (Volume 22, Issue 4) of Journal of Elections, Public Opinion, and Parties is devoted to the role of socialization and social networks
}

(C) Southern Regional Science Association 2017.

ISSN 1553-0892, 0048-749X (online)

www.srsa.org/rrs 
Figure 1: Reported Voting Rates by Age Groups

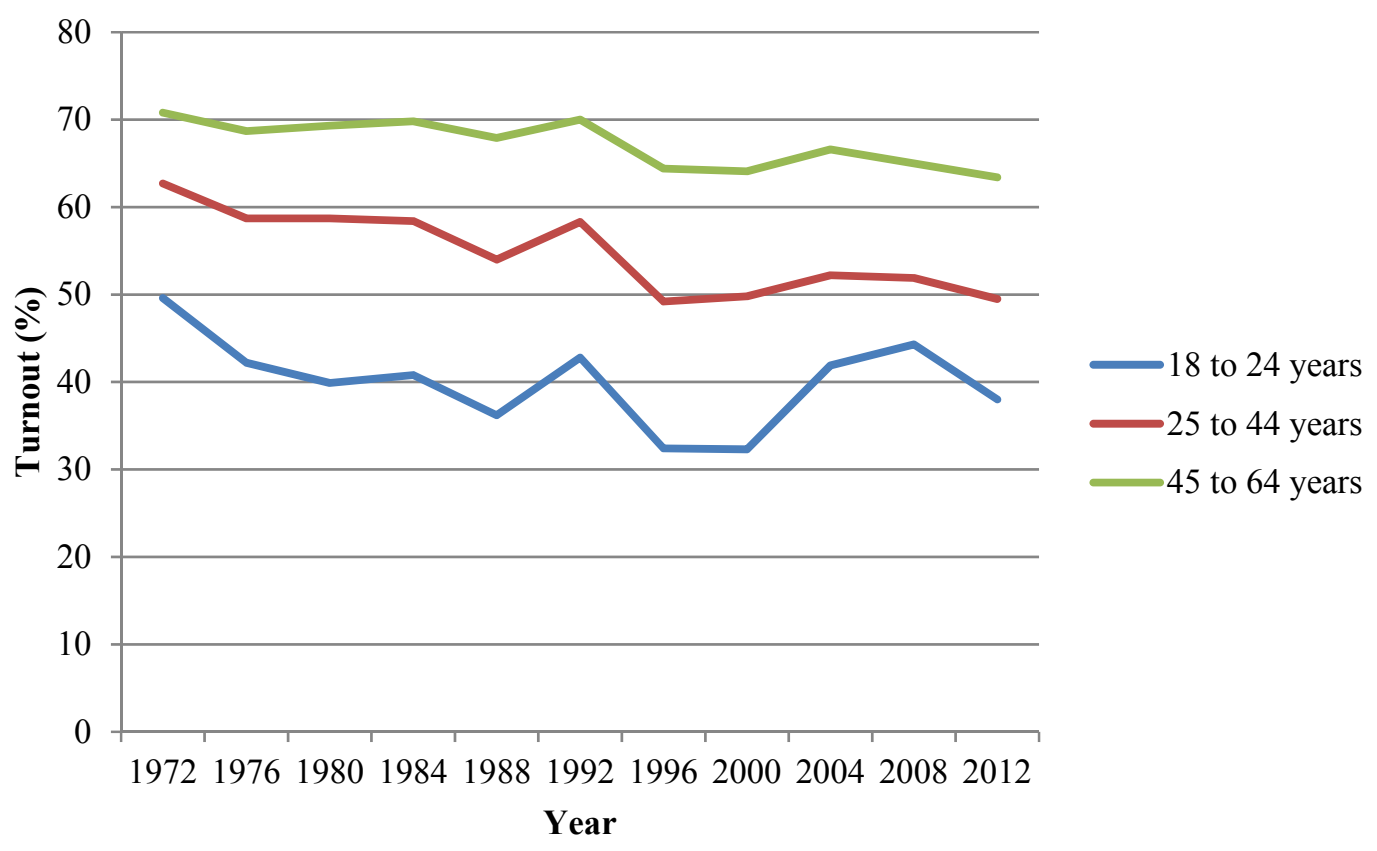

Note: Data taken from Census Bureau

on peers may shed more light on the puzzle of low youth voter turnout and may provide avenues for increasing political participation among young adults.

This paper seeks to understand how the influence of group norms and the types of group norms may affect the development of civic motivations later in life. We know that political participation is determined by an individual's level of resources, level of political engagement, and connection with recruitment (Verba, Schlozman, and Brady, 1995). There is strong evidence that increased civic engagement during adolescence also leads to greater political participation in adulthood (Campbell, 2008; Flanagan and Levine, 2010). For youths, adolescence is a period within which each of these political-participation factors develops through various mechanisms like civic education, service learning, and extracurricular activities. These types of engagement can teach organizational and leadership skills and can served as a recruitment tool towards political activity. The activities help facilitate development of civic identity and feelings of belonging. A large part of this development and social integration is acceptance by peers in school. Connections are formed in activities and are sometimes the goal in joining organizations or engaging in extracurricular activities (Denault and Poulin, 2009; Simpkins et al., 2012).

Schools have long been thought of as an agent of political socialization (Beck and Jennings 1982). American schools have included civic education as part of their curriculum as well as offer extracurricular activities. Classroom based civics courses can increase political knowledge as well as increase social capital (Galston, 2001; Kahne and Sporte, 2008). Research has consistently demonstrated that voluntary association participation is a predictor of political participation (Hart et al., 2007; Smith, 1999; Verba et al. 1995). Extra-curricular activities provide an integrative social function (Hanks and Eckland, 1976) by linking individuals to society (see Otto and Featherman, 1975). They enable civic education outside of the classroom through interaction with a group of peers striving for a common goal (Smith 1999). The skills 
developed throughout high school via these various civic engagement activities can transfer to political and civic activities later in life (Kirlin 2003).

This study addresses the influence of one's high-school peers on future political participation. Specifically, we estimate the potential spillover effects from the various forms of civic engagement, including civic education, volunteering, and extracurricular activities, on political participation. We make two contributions to the peer-effects literature. Our first is the application of spatial econometrics, specifically the spatial Durbin error model (SDEM), to the longitudinal study of peer effects in high school on outcomes during young adulthood. The SDEM is a local spillover specification that models spatial dependence in the error term: it has yet to be used outside of the study of neighbors based on geography. Our second contribution is the use of the coursework cluster as a peer group. Unlike previous studies that use classmates or social networks as peer groups, the coursework cluster takes into account multiple courses taken throughout the high school tenure. This is a unique group that can influence adolescents and this influence must be studied further.

Our results show that the influence of the peer group is primarily driven by those peers who perform better (have a higher grade point average) in social studies courses or who engage in extracurricular activities. Young adults are more apt to participate politically when they have high-achieving peers in their social studies courses. Given these findings, there is a role for classroom-based civics education in the high school and should not be ignored in the debate over the Common Core State Standards curriculum. As schools seek ways to meet today's challenges, this study provides insight on how social studies programs can have lasting impacts on political participation.

\section{DATA AND VARIABLES}

\subsection{Sample and Peer Group Construction}

The data for this study are taken from the National Longitudinal Study of Adolescent to Adult Health (Add Health). Beginning with an in-school questionnaire administered to a nationally representative sample of students in grades 7 through 12 in 1994-95, ${ }^{3}$ the study follows up with a series of in-home interviews of respondents approximately 1 year (Wave 2; 1996), 6 years (Wave 3; 2001-2002), and 13 years later (Wave 4; 2007-2008). Each wave contains general questions on demographics, family background, and friendship. A subset of these students was chosen to answer more detailed questions on a variety of behaviors. The main source of the data is from Wave 3, where the respondents are between the ages of 18 and 28 , where everyone in the sample is eligible to vote.

In Wave 3, there is a separate module, the Adolescent Health and Academic Achievement Study (AHAA), which provides detailed indicators of educational achievement, course-taking patterns, curricular exposure, and other education contexts. Roughly 91 percent of 15,172 respondents from Wave 3 had complete transcript information where these indicators are gathered. From the course-taking patters, clusters can be defined that place students in a group that participate in a unique set of courses. ${ }^{4}$ For example, a cluster can be defined for students who take Advanced Placement (AP) courses. The courses used to create these clusters are not

\footnotetext{
${ }^{3}$ Our sample only includes students when they were enrolled in high school.

${ }^{4}$ See Field et al. (2006) for a description of the algorithm used to create the various clusters.
} 
specific classes but a series of courses that are similar across the high schools in the survey. Each respondent is placed in a cluster with a set of other individuals from their school. The relationship with individuals in the coursework cluster may not be as strong as with friends, but it can provide varied access to different types of information and norms related to civic and political engagement. These individuals are assigned to 47 different clusters across all of the schools. Every school does not have all 47 clusters. In our sample, there are roughly 13 clusters per school. ${ }^{5}$ Within each cluster, the median number of peers is 11 , so respondents have roughly 11 classmates who take a similar set of courses throughout high school.

\subsection{Dependent Variable}

The dependent variable is Adult Political Participation, which is an index of civic and political activities that the respondent engages in during young adulthood. There are five items taken from Wave 3 of the Add Health Survey to create the index: 1) whether the respondent is registered to vote, 2) whether the respondent voted in the 2000 presidential election, 3) whether the respondent engages in volunteering, such as volunteers with a civic or community organization, 4) whether the respondent is involved in a political campaign, and 5) whether the respondent is a member of a political organization. Each of these items are dummy variables taking on the value of one if a respondent answers yes to any question, and zero otherwise. The index is created using Item-Response Theory (IRT), following the same method used in McFarland and Thomas (2006). ${ }^{6}$ IRT provides statistical models for the relationship between item response and a latent variable (Zheng and Rabe-Hesketh, 2007). The latent variable is civic identity, where the greater the identity the more likely the respondent will choose yes to any of the five questions. Using IRT creates a continuous variable where higher values of the index signify the respondent participates in more political and civic activities. These items fit with the classification of "formal political participation," as defined in Amna (2012). While we incorporate five factors that constitute formal political participation, a majority of participation is through voter registration and voting in the 2000 presidential election.

\subsection{Explanatory Variables}

The main explanatory variables represent civic engagement during adolescence. The definition of civic engagement follows Hart et al. (2007), where the authors outline three factors that represent civic engagement: civic knowledge, community service, and extracurricular activities. Civic knowledge is measured by the respondent's grade point average (GPA) in all the social studies courses completed by the respondent and the cumulative number of credits ${ }^{7}$ earned in all social studies courses (Credit). Social studies in this format refer to courses in one of the following six categories: history, political science/government/economics, geography, sociology/psychology, nonwestern studies, and other. ${ }^{8}$ The community service measure identifies whether or not the respondent participated in volunteer work when he or she was between the

\footnotetext{
${ }^{5}$ Crosnoe et al. (2008) have an average of 15 clusters per school using Add Health.

${ }^{6}$ We use the STATA programs GLLAMM and GLLAPRED to create the index. GLLAMM estimates the parameters of the IRT model, while GLLAPRED obtains the expected posterior (EAP) scores for each individual. The EAP scores are the index of political participation for each individual.

${ }^{7}$ One Carnegie credit is equivalent to three hours of instruction.

${ }^{8} \mathrm{We}$ are not able to separate the courses by specific topic. We do not know which specific set of courses within that group, only that the respondent took courses within that set of topics.
}

(c) Southern Regional Science Association 2017. 
ages of 12 and $18 .{ }^{9}$ It is coded as a dummy variable equal to one if the respondent engaged in volunteering, and zero otherwise. Extracurricular activities are measured as the aggregation of all the activities listed in the in-school survey. ${ }^{10}$ While this does not cover the entirety of the highschool experience, we can think of this variable as representing the fact that the individual participated in a given activity at some point during their high school experience. This activity measure tests how the breadth of activities affects participation. Since this is an aggregated measure, it cannot speak to the mechanism through which activity participation leads to later political participation. We also include the number of activities squared to account for possible nonlinear effects (Fredricks and Eccles, 2010).

\subsection{Controls}

To isolate the effect of civic engagement on political participation, we must control for variables that are associated with participation. Therefore, we use control variables from the resource model of political participation (Brady, Verba, and Schlozman, 1995). These standard variables may not pertain to this sample because the respondents face different factors that older age cohorts do not face (Highton and Wolfinger, 2001; Niemi and Hanmer, 2010). We include gender, age, ethnicity, education, residential stability, occupational status, home ownership, religious attendance, marital status, and partisan identification. The gender variable is a dummy variable equal to one if the respondent is female and zero otherwise. Age is a continuous variable. Ethnicity and racial indicator variables are included for if the individual is AfricanAmerican, Hispanic, Native American, and Asian; White is the omitted group. Education is separated into two categories: those who are enrolled in college part-time, and those who are enrolled in college full-time. Residential stability (Not a mover) is a dummy variable equal to one if the respondent still lives in the same house they grew up in and zero otherwise. ${ }^{11}$ Occupational status (Working) is a dummy variable equal to one if the respondent works more than ten hours a week and zero otherwise. Homeownership is a dummy variable equal to one if the respondent owns his/her home and zero otherwise. Religious attendance is a dummy variable equal to one if the respondent attends religious services at least once a week and zero otherwise. $^{12}$ Marital status (Married) is a dummy variable equal to one if the respondent is married and zero otherwise. One dummy variable represents partisan identification. i.e., whether an individual identifies as either a Democrat or a Republican. We also include two measures to control for the political context. The political context measures include the difference ${ }^{13}$ in the proportion of Democratic votes and Republican votes for President at the county level (Political Competition) and the proportion of the population that works outside of their county of residence (Commuting). This measure can be thought of as the proportion of the population that commutes for work. This is a proxy for community investment (Putnam, 2000). The total number of observations in the sample is 9,989. Table 1 provides descriptive statistics of all variables.

\footnotetext{
${ }^{9}$ Out of the sample that engaged in volunteering, 20\% of them were required to volunteer. We run models separating this measure into voluntary and required volunteer activities. Both types of volunteering has statistically significant direct effects but not statistically significant indirect effects at the $95 \%$ level. Voluntary activities have a coefficient of 0.4236 and required activities have a coefficient of 0.3505 .

${ }^{10}$ As with Brown (2011), we cap the number of activities at ten. Less than $1 \%$ of the sample engaged in more than ten activities.

${ }^{11} \mathrm{We}$ do not have information about whether they moved within neighborhoods, only if they moved out of state.

12 Religious services include attending a mosque or synagogue in addition to church services.

${ }^{13}$ We take the absolute value of the measure so that it can represent how competitive the tract is. The larger the value the less competitive the tract.
}

(c) Southern Regional Science Association 2017. 
Table 1: Descriptive Statistics of Study Variables

\begin{tabular}{|c|c|c|c|c|}
\hline Variable $(n=9,989)$ & Mean & Std. Dev. & Min & Max \\
\hline \multicolumn{5}{|l|}{ Dependent Variable } \\
\hline Adult Political Participation & 0.17 & 1.51 & -2.07 & 4.84 \\
\hline \multicolumn{5}{|l|}{ Civic Engagement } \\
\hline Social studies GPA & 2.58 & 0.91 & 0 & 4 \\
\hline Social studies credits & 3.6 & 1.08 & 0 & 11 \\
\hline Volunteered in High School & $46.3 \%$ & 0.50 & 0 & 1 \\
\hline Extracurricular Activities & 2.3 & 2.43 & 0 & 33 \\
\hline \multicolumn{5}{|l|}{ Controls } \\
\hline Gender $($ Female $=1)$ & $52.7 \%$ & 0.50 & 0 & 1 \\
\hline Age & 22.5 & 1.20 & 18 & 27 \\
\hline White (omitted group) & $56.8 \%$ & 0.50 & 0 & 1 \\
\hline Black & $18.7 \%$ & 0.39 & 0 & 1 \\
\hline Hispanic & $16.0 \%$ & 0.37 & 0 & 1 \\
\hline Native & $2.7 \%$ & 0.16 & 0 & 1 \\
\hline Asian & $10.0 \%$ & 0.30 & 0 & 1 \\
\hline Not a Mover & $89.8 \%$ & 0.30 & 0 & 1 \\
\hline Working (10+ hours) & $10.3 \%$ & 0.30 & 0 & 1 \\
\hline Homeowner & $28.0 \%$ & 0.45 & 0 & 1 \\
\hline Attend Religious Services & $17.1 \%$ & 0.38 & 0 & 1 \\
\hline Attend College Part-time & $75.3 \%$ & 0.43 & 0 & 1 \\
\hline Attend College Full-time & $13.6 \%$ & 0.34 & 0 & 1 \\
\hline Married & $18.3 \%$ & 0.39 & 0 & 1 \\
\hline Partisan Identification & $17.7 \%$ & 0.38 & 0 & 1 \\
\hline Political Competition & $36.2 \%$ & 0.48 & 0 & 1 \\
\hline Commuting & 0.20 & 0.15 & 0 & 0.794 \\
\hline
\end{tabular}

\section{RESEARCH APPROACH}

Spatial econometrics provides models for situations where sample data observations are taken with reference to regions on a map. The regions can be as large as a country or as small as a census tract. Such data often exhibit spatial dependence as the actions in one region impact those in a neighboring region (Anselin, 1988). The dependence structure is given in a weight matrix, which defines the relationship between the regions. If these units are individuals instead of regions, we obtain a social interactions model. In this case, the actions of one individual impact the actions of a "neighboring" individual, such as a peer. Several studies apply spatial econometric methods to the study of peer effects and adolescent behavior (Ajilore, 2015; Boucher, 2014; Lin, 2014).

There are several different types of spatial models that depend on whether we want to estimate a local spillover or a global spillover. The local spillover specification denotes the impact of an entity's action or characteristic on a neighboring entity without endogenous

(c) Southern Regional Science Association 2017. 
feedback effects. The global spillover specification denotes the same impact, but includes the endogenous feedback effects. Endogenous feedback effects occur when the initial impact on the neighboring entity causes impacts on subsequent neighbors and so on. A common model using the global spillover specification is the Spatial Durbin Model (SDM), given as:

(1) $y_{r}=\alpha_{r}+\beta_{0} W_{r} y_{r}+\beta_{1} x_{r}+\beta_{2} W_{r} x_{r}+\varepsilon_{r}$

The $\beta_{0} W_{r} y_{r}$ term represents the endogenous feedback effects. $W_{r}$ is the weight matrix used to express the connections between the individuals in the coursework cluster. LeSage (2014) argues that the global spillover specification is rarer than the local spillover specification and thus, should be used less frequently. In our study, we will focus on the local spillover specification, though there may be an argument that the impact of the actions of one individual may have feedback effects through different peer networks.

\subsection{Local Spillover Specifications}

One type of local spillover specification is called in the Spatial Lag Model (SLX), which can be expressed as:(2) $y_{r}=\alpha_{r}+\beta_{1} x_{r}+\beta_{2} W_{r} x_{r}+\varepsilon_{r}$

A second local spillover specification extends the SLX model by incorporating spatial dependence in the error term, which is called the Spatial Durbin Error Model (SDEM). The spatial dependence refers to global spatial shocks that distinguish it from spillovers associated with explanatory variables. The SDEM is expressed as:

(3) $y_{r}=\alpha_{r}+\beta_{1} x_{r}+\beta_{2} W_{r} x_{r}+u_{r}, u_{r}=\lambda W u_{r}+\varepsilon_{r}$

Again, $W_{r}$ is the weight matrix. This specification accounts for residual spatial correlation. There may be unobserved factors that vary systematically over space. In our application, these unobserved factors do not vary across space, but vary across the coursework cluster. When interpreting the coefficients obtained from a spatial model, there are concerns regarding the magnitude of the effects due to the spatial parameters. Since there are no endogenous feedback effects in the local spillover specifications, the coefficients represent marginal effects, where $\beta_{1}$ is the estimate of the direct effect and $\beta_{2}$ is that for the indirect effect. The coefficient estimated for the direct effect provides the marginal effect of the explanatory variable on political participation. The coefficient estimated for the indirect effect will give us the influence of peers on future political participation.

Since the research question asks whether civic engagement by peers impacts future political participation, we are only concerned with past peer behavior and not current peer behavior. ${ }^{14}$ The spatially lagged variables include those that pertain to the peer group. Civic engagement that occurred during the high school years will inform the longitudinal impact of those activities on adult political participation. Our estimating equation focusing on peer civic engagement is given by:

(3') $y_{r}=\alpha_{r}+\beta_{1} x_{r}+\beta_{2} C E_{r}+\beta_{3} W_{r} C E_{r}+u_{r}, u_{r}=\lambda W u_{r}+\varepsilon_{r}$

$x_{r}$ are the control variables and $C E_{r}$ are the civic engagement measures outlined in Table 1. In $\left(3^{\prime}\right), \beta_{1}$ and $\beta_{2}$ are the direct effects estimates and $\beta_{3}$ is the indirect effects estimates that will show the impact of peer civic engagement on political participation.

${ }^{14}$ Models that test current peer behavior include endogenous feedback effects as a spatially lagged dependent variable.

(C) Southern Regional Science Association 2017. 
As shown in $\left(3^{\prime}\right)$, only the civic engagement measures are spatially weighted. We do not spatially weight the other explanatory variables because we are looking at two different time periods. The peer influence occurs during high school, while the outcome measure and the control variables occur during young adulthood. We are only concerned with the influence of those peers who were part of the same coursework cluster during high school and whether this influence has long-run impacts.

\subsection{Bayesian Model Comparison}

It is the convention within the literature to use a Bayesian approach to estimate spatial models. Using Bayesian analysis allows for model comparisons in a statistically coherent manner. Following LeSage and Pace (2009), we implement the Markov Chain Monte Carlo (MCMC) estimation procedure. ${ }^{15}$ These techniques provide a more tractable method to derive the standard errors for the marginal effects (Jensen, Lacombe, and McIntyre, 2013; LeSage and Dominguez, 2012).

Since we are estimating multiple spatial models testing for local spillover effects, Bayesian model comparison techniques will be useful to compare each model. While the theoretical context points to specifying only models with local spillovers, the technique may be useful to further differentiate between the two local spillover specifications, the SLX and SDEM. The technique produces log-marginal likelihoods for each model specification. Model probabilities are calculated for each of the models using the marginal likelihood and the model with the highest posterior probability is the preferred model. LeSage (2015) outlines a single MATLAB function that calculates Bayesian posterior model probabilities for three spatial models: SLX, Spatial Durbin Model (SDM), and SDEM.

\section{RESULTS}

We estimate the effect of civic engagement activities and civic engagement by peers during high school on political participation. Our goal is to see how a peer's involvement in civic engagement activities during high school affects political participation several years later. But first we want to find the proper model to estimate the peer effects. Table 2 provides the model probabilities for the Bayesian model comparison of the local spillover models, along with the Spatial Durbin Model (SDM). ${ }^{16}$

The results in Table 2 indicate that the SDEM is the preferred model, as this model produces the highest posterior model probability. Table 3 provides the results of the model specified in $\left(3^{\prime}\right)$ including the peer civic engagement measures for the SDEM.

Table 2. Log-Marginal Likelihood Values and Posterior Model Probabilities

\begin{tabular}{lcc}
\hline Model & Log-marginal likelihood value & Posterior Model Probability \\
\hline Spatially Lagged X (SLX) & $-21,282.06$ & 0.000 \\
Spatial Durbin (SDM) & $-21,239.48$ & 0.336 \\
Spatial Durbin Error (SDEM) & $-21,238.80$ & 0.664 \\
\hline
\end{tabular}

\footnotetext{
${ }^{15}$ In Chapter 5 of LeSage and Pace (2009), the authors provide the mathematical and computational details of the Bayesian approach.

${ }^{16}$ The MATLAB command lmarginal_cross_section reports the results for all three models (LeSage, 2015).

(C) Southern Regional Science Association 2017.
} 
Civic education has a positive direct effect on political participation. Having a higher GPA has a greater impact than just earning credits by taking courses. This result is consistent with previous research (Niemi and Junn, 1998; Sherrod, 2003; Torney-Purta, 2002). Respondents who volunteered in high school are more likely to participate, which is also consistent with the literature (Berry, Portman, Thomas 1993; Rosenstone and Hansen 1993; Verba et al. 1995). Respondents who engage in more extracurricular activities are more likely to participate, but this effect is diminished as the number of activities increases. This finding is consistent with other research on extracurricular activities (Eccles and Barber, 1999; Feldman and Matjasko, 2005; Fredricks and Eccles, 2006; Glanville, 1999; Zaff, Malanchuk, and Eccles, 2008).

For peer effects, the results show that coursework cluster peers have an impact based on if the peers are high-achieving peers. Having peers with a higher GPA in social studies courses is positively correlated with political participation. This positive relationship could be due to the fact that cluster peers provide an avenue of competition where adolescents use these peers to set the bar for achievement. Since the adolescent is taking multiple courses with these peers, these peers provide competition where each term they push the individual to achieve. Peers also have an impact through participation in extracurricular activities. Engaging in extracurricular activities allows for connections to form and these connections may provide an avenue for the transmission of civic norms.

Turning to the control variables, Black respondents, those who attend college, those who are religious, and those who identify with a political party are more likely to participate. Education and party identification have been shown in the literature to be the strongest predictor of voter turnout (Smets and van Ham, 2013). Southwell and Pirch (2003) found that in 2000, the participation gap between Blacks and Whites had closed. Hispanic and Asian respondents are less likely than White respondents to participate. Since 1998, Hispanic and Asian voter turnout have tracked closely together and lag behind the rates of Whites and Blacks. ${ }^{17}$ Highton and Burris (2002) find that even controlling for the fact that many Latinos are not eligible, voter turnout is low. Older respondents, young women, and married respondents are less likely to participate. While this is contrast to the literature, this is a sample of young adults and what is true for the general population may not be true for young adults.

The results also show that connection to the community is important. Respondents who lived in the neighborhood for a long time and homeowners are more likely to participate. Respondents who live in a county with a lot of commuters are less likely to participate. In this case, working outside the community, may lessen the attachment to the community, which could result in lower rates of participation. While we did not explicitly test this, urban scholars suggest that there is a close relationship between community attachment and participation. This may explain why homeowners and respondents who live long-term in their neighborhood are more likely to participate. Dowding, John, and Rubenson (2012) find that individuals who are more connected in their community are more likely to vote.

\footnotetext{
${ }^{17}$ Data is taken from Figure 10 of the Pew Research Center report "Millennials Make Up Almost Half of the Latino Eligible Voters in 2016" (Krogstad et al., 2016)
}

(c) Southern Regional Science Association 2017. 
Table 3. Effect of Peer Civic Engagement on Political Participation

\begin{tabular}{|c|c|c|}
\hline & Direct Effect & Indirect Effect \\
\hline Social studies GPA & $\begin{array}{c}0.1065^{* * *} \\
(0.019)\end{array}$ & $\begin{array}{c}0.0929 * * \\
(0.034)\end{array}$ \\
\hline Social studies Credits & $\begin{array}{c}0.0424 * * * \\
(0.014)\end{array}$ & $\begin{array}{l}-0.0087 \\
(0.024)\end{array}$ \\
\hline Volunteered in High School & $\begin{array}{c}0.4075 * * * \\
(0.028)\end{array}$ & $\begin{array}{l}0.0833 \\
(0.072)\end{array}$ \\
\hline Extracurricular Activities & $\begin{array}{c}0.0791 * * * \\
(0.010)\end{array}$ & $\begin{array}{l}0.0490 * \\
(0.022)\end{array}$ \\
\hline Activities Squared & $\begin{array}{c}-0.0036^{* * * *} \\
(0.001)\end{array}$ & $\begin{array}{c}-0.0028^{* *} \\
(0.001)\end{array}$ \\
\hline Gender $($ Female $=1)$ & $\begin{array}{c}-0.0740^{* *} \\
(0.028)\end{array}$ & \\
\hline Age & $\begin{array}{c}-0.0549 * * * \\
(0.004)\end{array}$ & \\
\hline Black & $\begin{array}{c}0.2227 * * * \\
(0.039)\end{array}$ & \\
\hline Hispanic & $\begin{array}{c}-0.2475^{* * *} * \\
(0.043)\end{array}$ & \\
\hline Native & $\begin{array}{l}0.0402 \\
(0.086)\end{array}$ & \\
\hline Asian & $\begin{array}{c}-0.5617 * * * \\
(0.052)\end{array}$ & \\
\hline Not a Mover & $\begin{array}{c}0.0998^{* *} \\
(0.037)\end{array}$ & \\
\hline Working $(10+$ hours $)$ & $\begin{array}{l}0.0160 \\
(0.032)\end{array}$ & \\
\hline Homeowner & $\begin{array}{c}0.1209 * * * \\
(0.042)\end{array}$ & \\
\hline Attend Religious Services & $\begin{array}{c}0.1156^{* * *} \\
(0.036)\end{array}$ & \\
\hline Attend College Part-time & $\begin{array}{c}0.1804 * * * \\
(0.045)\end{array}$ & \\
\hline Attend College Full-time & $\begin{array}{c}0.1797 * * * \\
(0.033)\end{array}$ & \\
\hline Married & $\begin{array}{c}-0.1203^{* *} \\
(0.039)\end{array}$ & \\
\hline Partisan Identification & $\begin{array}{c}0.8545 * * * \\
(0.029)\end{array}$ & \\
\hline Political Competition & $\begin{array}{c}0.2850^{* *} \\
(0.099)\end{array}$ & \\
\hline Commuting & $\begin{array}{c}-0.2520 * * \\
(0.088)\end{array}$ & \\
\hline$L a m b d a$ & $\begin{array}{c}0.1056^{* * * *} \\
(0.017)\end{array}$ & \\
\hline
\end{tabular}

(C) Southern Regional Science Association 2017. 


\section{DISCUSSION}

Conventional wisdom originally suggested that classroom-based education had no statistically significant effects on political knowledge (Langton and Jennings, 1968). But "conventional wisdom" changed with the study by Niemi and Junn (1998) that used data from the National Assessment of Educational Progress (NAEP) Civic Assessment test. The authors show that civic coursework raises political knowledge by 4 percent. Other authors have shown that formal classroom education is positively related to political participation (Bachner, 2010; Callahan, Mueller, and Schiller, 2010; Dassonnville et al., 2012; Pasek et al., 2007). Our findings take these results a step further and find that peers who have higher achievement in Social studies courses are positively related to the political participation of young adults. We did not find any other significant peer effects in other forms of civic engagement.

The positive spillover effect of achievement is consistent with the research on peer effects and academic achievement [see Sacerdote (2014) for a review]. While most of those studies focus on average peer effects, Lavy, Paserman, and Schlosser (2012) found that highability students benefit from being with other high-ability peers. Our results show that this is true with respect to coursework in Social studies. In contrast to this literature that focuses on contemporaneous influence, our results show that this influence persists through young adulthood. Other scholars have found evidence of a longitudinal impact of peers on educational and labor market outcomes (Black, Devereux, and Salvanes, 2013; Bifulco et al., 2014). Unlike this research, our study uses a new specification of the peer group with individuals who take a series of courses throughout high school. While these individuals may not consider each other "friends," they interact in high school within the classroom. Also, these individuals take multiple courses together so this familiarity may strengthen these ties.

Research has consistently demonstrated that voluntary association participation is a predictor of political participation (Rosenstone and Hansen, 1993; Verba et al., 1995). Adolescents who engage in a variety of activities are able to develop a civic identity that translates into different forms of community and political participation as adults (Glanville, 1999; Quintelier, 2008; Wentzel and McNamara, 1999; Yates and Youniss, 1998). The findings show a positive spillover effect with extracurricular activities. While we do not have information about the interactions that occur within the coursework cluster, our results show that norms developed towards civic identity can pass through to peers within the cluster. Future research will analyze the type of activities that promote civic identity and how these norms translate into political participation.

\section{CONCLUSION}

In this paper, we try to understand whether peer involvement in civic engagement activities have spillover effects on adolescents in political participation when they are older. We define the peer group as the set of classmates that take a particular group of courses using the algorithm developed by Field et al. (2006). This coursework cluster is differentiated from the customary social network that is comprised of friends. Individuals in the coursework cluster are not necessarily friends but are in close proximity with each other throughout their high school tenure. In these classes, these individuals may be working together and through observation or competition may influence each other. Understanding whether there is an influence from these peers can provide further knowledge on the role of high school peers. 
This study showed the importance of involvement in civic engagement during high school. Taking and excelling in social studies courses were positively correlated with political participation during young adulthood. Volunteering, whether it is voluntary or required, was positively correlated with participation. Finally, engaging in extracurricular activities was positively correlated with participation, though this effect exhibited diminishing returns. These results are not completely generalizable because there are some limitations pertaining to the dataset. The data do not give detail on type of courses or classroom experiences, so we cannot speak to how the Social Studies courses are taught. An important aspect of classroom-based civics education is the manner in which the courses are taught (Hooghe and Dassonneville, 2011; Martens and Gainous, 2013). The outcome variables we used to measure voter turnout and registration are self-reported, so it is possible that there is a response bias. Finally, our data is a sample of adolescents who were in high school during the 1990s when there were fewer statelevel civics education requirements. Now, over 80 percent of states currently have some sort of civics education requirements.

The findings highlight the added importance of achievement in social studies courses, as well as participation in extracurricular activities, as influences on political participation in young adulthood. Adolescents with peers who have a higher GPA in social studies courses are more likely to be politically active as young adults. Using Add Health data, Bachner (2010) and Callahan et al. (2010) find positive effects between social science coursework and voting behavior. Our results show that peer achievement in these courses have similar effects for our measure of political participation, which includes other forms of participation besides voting. Like Bachner (2010) and Callahan et al. (2010), our results support the claim that more social science coursework can counteract the absence of political socialization at home and through other social connections. When structuring high-school course curricula, it is imperative that school administrators and state policy makers understand the role of social science courses and their impact on young adult political participation.

\section{REFERENCES}

Ajilore, Olugbenga. (2015) "Identifying Peer Effects Using Spatial Analysis: The Role of Peers on Risky Sexual Behavior," Review of Economics of the Household, 13, 635-652.

Amnå, Erik. (2012) "How is Civic Engagement Developed Over Time? Emerging Answers from a Multidisciplinary Field," Journal of Adolescence, 35, 611-627.

Anselin, Luc. (1988) Spatial Econometrics: Methods and Models. Springer: Dordrecht, Netherlands.

Bachner, Jennifer. (2010) "From Classroom to Voting Booth: The Effect of Civic Education on Turnout," Paper presented at the annual meeting of the Southern Political Science Association, New Orleans.

Beck, Paul Allen and M. Kent Jennings. (1982) "Pathways to Participation," American Political Science Review, 76, 94-108.

Bifulco, Robert, Jason M. Fletcher, Sun Jung Oh, and Stephen L. Ross. (2014) "Do High School Peers Have Persistent Effects on College Attainment and Other Life Outcomes?," Labour Economics, 29, 83-90.

(C) Southern Regional Science Association 2017. 
Black, Sandra E., Paul J. Devereux, and Kjell G. Salvanes. (2013) "Under pressure? The effect of peers on outcomes of young adults," Journal of Labor Economics 31, 119-153.

Boucher, Vincent, et al. (2014) "Do Peers Affect Student Achievement? Evidence from Canada Using Group Size Variation,” Journal of Applied Econometrics, 29, 91-109.

Brady, Henry E., Sidney Verba, and Kay Lehman Schlozman. (1995) "Beyond SES: A Resource Model of Political Participation," American Political Science Review, 89, 271-294.

Callahan, Rebecca, Kathryn Schiller, and Chandra Muller. (2010) "Preparing the Next Generation for Electoral Engagement: Social Studies and the School Context," American Journal of Education, 116, 525-556.

Campbell, David E. (2006) Why We Vote: How Schools and Communities Shape Our Civic Life. Princeton University Press: Princeton, New Jersey.

Crosnoe, Robert, Catherine Riegle-Crumb, Kenneth Frank, Sam Field, and Chandra Muller. (2008) "Peer Group Contexts of Girls' and Boys' Academic Experiences," Child Development, 79, 139-155.

Dassonneville, Ruth, Ellen Quintelier, Marc Hooghe, and Ellen Claes. (2012) "The Relation between Civic Education and Political Attitudes and Behavior: A Two-year Panel Study among Belgian Late Adolescents," Applied Developmental Science, 16, 140-150.

Denault, Anne-Sophie and François Poulin. (2009) "Intensity and Breadth of Participation in Organized Activities during the Adolescent Years: Multiple Associations with Youth Outcomes," Journal of Youth and Adolescence, 38, 1199-1213.

Dowding, Keith, Peter John, and Daniel Rubenson. (2012) "Geographic Mobility, Social Connections and Voter Turnout," Journal of Elections, Public Opinion \& Parties, 22, 109-122.

Farb, Amy Feldman and Jennifer L. Matjasko. (2012) "Recent Advances in research on Schoolbased Extracurricular Activities and Adolescent Development," Developmental Review, 32, 1-48.

Feldman, Amy F. and Jennifer L. Matjasko. (2005) "The Role of School-based Extracurricular Activities in Adolescent Development: A Comprehensive Review and Future Directions," Review of Educational Research, 75, 159-210.

Field, Sam, Kenneth A. Frank, Kathryn Schiller, Catherine Riegle-Crumb, and Chandra Muller. (2006) "Identifying Positions from Affiliation Networks: Preserving the Duality of People and Events," Social Networks, 28, 97-123.

File, Thom. (2014) "Young-adult Voting: An Analysis of Presidential Elections, 1964-2012," Department of Commerce: Washington, DC.

Flanagan, Constance and Peter Levine. (2010) "Civic Engagement and the Transition to Adulthood," Future of Children, 20, 159-179.

Fredricks, Jennifer A. and Jacquelynne S. Eccles. (2006) "Is Extracurricular Participation Associated with Beneficial Outcomes? Concurrent and Longitudinal Relations," Developmental Psychology, 42, 698-713.

(c) Southern Regional Science Association 2017. 
. (2010) "Breadth of Extracurricular Participation and Adolescent Adjustment among African-American and European-American Youth," Journal of Research on Adolescence, 20,307-333.

Galston, William A. (2001) "Political Knowledge, Political Engagement, and Civic Education," Annual Review of Political Science, 4, 217-234.

Glanville, Jennifer L. (1999) "Political Socialization or Selection? Adolescent Extracurricular Participation and Political Activity in Early Adulthood," Social Science Quarterly, 80, 279-291

Hanks, Michael P. and Bruce K. Eckland. (1976) "Athletics and Social Participation in the Educational Attainment Process," Sociology of Education, 49, 271-294.

Hart, Daniel, Thomas M. Donnelly, James Youniss, and Robert Atkins. (2007) "High School Community Service as a Predictor of Adult Voting and Volunteering," American Educational Research Journal, 44, 197-219.

Highton, Benjamin and Arthur L. Burris. (2002) "New Perspectives on Latino Voter Turnout in the United States," American Politics Research, 30, 285-306.

Highton, Benjamin and Raymond E. Wolfinger. (2001) "The First Seven Years of the Political Life Cycle," American Journal of Political Science, 45, 202-209.

Hooghe, Marc and Ruth Dassonneville. (2011) "The Effects of Civic Education on Political Knowledge. A Two Year Panel Survey among Belgian Adolescents," Educational Assessment, Evaluation and Accountability, 23, 321-339.

Jensen, Christa D., Donald J. Lacombe, and Stuart G. McIntyre. (2013) "A Bayesian Spatial Econometric Analysis of the 2010 UK General Election," Papers in Regional Science, $92,651-666$.

Kahne, Joseph E. and Susan E. Sporte. (2008) "Developing Citizens: The Impact of Civic Learning Opportunities on Students' Commitment to Civic Participation," American Educational Research Journal, 45, 738-766.

Kirlin, Mary. (2013) "The Role of Adolescent Extracurricular Activities in Adult Political Participation," Center for Information and Research on Civic Learning and Engagement (CIRCLE) Working Paper 02. University of Maryland: College Park, MD.

Langton, Kenneth P. and M. Kent Jennings. (1968) "Political Socialization and the High School Civics Curriculum in the United States," American Political Science Review, 62, 852867.

Lavy, Victor, M. Daniele Paserman, and Analia Schlosser. (2012) "Inside the Black Box of Ability Peer Effects: Evidence from Variation in the Proportion of Low Achievers in the Classroom," Economic Journal, 122, 208-237.

LeSage, James P. (2014) "What Regional Scientists Need to Know About Spatial Econometrics," Review of Regional Studies, 44, 13-32.

. (2015) "Software for Bayesian Cross Section and Panel Spatial Model Comparison," Journal of Geographical Systems, 17, 297-310.

(C) Southern Regional Science Association 2017. 
LeSage, James P. and Matthew Dominguez. (2012) "The Importance of Modeling Spatial Spillovers in Public Choice Analysis," Public Choice, 150, 525-545.

LeSage, James P., and Robert Kelley Pace. (2009) Introduction to Spatial Econometrics. CRC Press: Boca Raton, Florida.

Lin, Xu. (2014) "Peer Effects in Adolescents' Delinquent Behaviors: Evidence from a Binary Choice Network Model," Regional Science and Urban Economics, 46, 73-92.

Martens, Allison M. and Jason Gainous. (2013) "Civic Education and Democratic Capacity: How Do Teachers Teach and What Works?," Social Science Quarterly, 94, 956-976.

McFarland, Daniel A. and Reuben J. Thomas. (2006) "Bowling Young: How Youth Voluntary Associations Influence Adult Political Participation," American Sociological Review, 71, 401-425.

Niemi, Richard G. and Michael J. Hanmer. (2010) "Voter Turnout Among College Students: New Data and a Rethinking of Traditional Theories," Social Science Quarterly, 91, 301323.

Niemi, Richard G. and Jane Junn. (1998) Civic Education: What Makes Students Learn. Yale University Press: New Haven, CT.

Otto, Luther B. and David L. Featherman. (1975) "Social Structural and Psychological Antecedents of Self-estrangement and Powerlessness," American Sociological Review, 40, 701-719.

Pasek, Josh, Lauren Feldman, Daniel Romer, and Kathleen H. Jamieson. (2008) "Schools as Incubators of Democratic Participation: Building Long-term Political Efficacy with Civic Education," Applied Development Science, 12, 26-37.

Putnam, Robert D. (2001) Bowling Alone. Simon \& Schuster: New York.

Quintelier, Ellen. (2008) "Who is Politically Active: The Athlete, the Scout Member or the Environmental Activist? Young People, Voluntary Engagement and Political Participation," Acta Sociologica, 51, 355-370.

Rosenstone, Steven and John M. Hansen. (1993) Mobilization, Participation and Democracy in America. Macmillan Publishing: London.

Sacerdote, Bruce. (2014) "Experimental and Quasi-experimental Analysis of Peer Effects: Two Steps Forward?," Annual Review of Economics, 6, 253-272.

Sherrod, Lonnie R. (2003) "Promoting the Development of Citizenship in Diverse Youth," Political Science and Politics, 36, 287-292.

Simpkins, Sandra D., Andrea E. Vest, Melissa Y. Delgado, and Chara D. Price. (2012) "Do School Friends Participate in Similar Extracurricular Activities? Examining the Moderating Role of Race/Ethnicity and Age," Journal of Leisure Research, 44, 332-352.

Smets, Kaat and Carolien van Ham. (2013) "The Embarrassment of Riches? A Meta-analysis of Individual-level Research on Voter Turnout," Electoral Studies, 32, 344-359.

Smith, Elizabeth S. (2002) "The Effects of Investments in the Social Capital of Youth on Political and Civic Behavior in Young Adulthood: A Longitudinal Analysis," Political Psychology, 20, 553-580.

(C) Southern Regional Science Association 2017. 
Southwell, Priscilla L. and Kevin D. Pirch. (2003) "Political Cynicism and the Mobilization of Black Voters," Social Science Quarterly, 84, 906-917.

Thomas, Reuben J. and Daniel A. McFarland. (2010) "Joining Young, Voting Young: The Effects of Youth Voluntary Associations on Early Adult Voting," Center for Information and Research on Civic Learning and Engagement (CIRCLE) Working Paper 73. University of Maryland: College Park, Maryland.

Torney-Purta, Judith. (2002) "The School's Role in Developing Civic Engagement: A Study of Adolescents in Twenty-eight Countries," Applied Developmental Science, 6, 203-212.

Verba, Sidney, Kay L. Schlozman, and Henry E. Brady. (1995) Voice and Equality: Civic Voluntarism in American Politics. Harvard University Press: Cambridge, Massachusetts.

Wentzel, Kathryn R. and Carolyn C. McNamara. (1999) "Interpersonal Relationships, Emotional Distress, and Prosocial Behavior in Middle School," Journal of Early Adolescence, 19, $114-125$.

Yates, Miranda and James Youniss. (1998) "Community Service and Political Identity Development in Adolescence,” Journal of Social Issues, 54, 495-512.

Zaff, Jonathan F., Oksana Malanchuk, and Jacquelynne S. Eccles. (2008) "Predicting Positive Citizenship from Adolescence to Young Adulthood: The Effects of a Civic Context," Applied Development Science, 12, 38-53.

Zheng, Xiaohui and Sophia Rabe-Hesketh. (2007) "Estimating Parameters of Dichotomous and Ordinal Item Response Models with GLLAMM,” Stata Journal, 7, 313-333. 